\title{
Examination of the Relationship Between Social Studies Teacher Candidates of Pre-Service Teacher Identity Levels And Possible Self-Esteem Levels*
}

Kamil UYGUN**

\author{
Mehmet Akif KARALI ${ }^{* * *}$
}

\begin{abstract}
This research was prepared to investigate the relationship between possible self-esteem levels and prevocational teacher identity levels of social studies teacher candidates. The research was prepared in accordance with the relational screening model. In this research was used appropriate sampling method and the study, in the academic year of 2017-2018; Uşak University, Muğla Sitkı Koçman University, Afyon Kocatepe University and Aksaray University have been conducted with 290 prospective teachers who have been educated in the department of social studies teaching of the education faculties. The relationship between prevocational teacher identity levels and probable self-esteem levels of social studies teacher candidates has been investigated using the Pearson Moments Multiplication Correlation Analysis. As a result of the research, it was seen that prevocational teacher identities and expected possible self-esteems of social studies teacher candidates are high, and feared probable self-esteem are low. It has been determined that social studies teacher candidates have a positive direction, linear and intermediate relationship between their prevocational teacher identity levels and their expected possible self-esteem levels. It has been determined that the social studies teacher candidates have a negative direction, linear and intermediate relationship between their prevocational teacher identity levels and their feared possible self- esteem levels.
\end{abstract}

Keywords: Social studies, Prevocational teacher identity, Possible self-esteems

\footnotetext{
${ }^{*}$ This study was produced from the master thesis of the second author under the supervision of the first author. Supported by UBAP 06 with number 2018/TP008. This study was presented as an oral presentation in the USBES 7th International Social Studies Education Symposium.

** Orcid id: https://orcid.org/0000-0002-8971-328X, Assist. Prof. Dr., Uşak University, Faculty of Education, Department of Turkish and Social Sciences Education, kamil.uygun@usak.edu.tr

${ }^{* * *}$ Orcid id: https://orcid.org/0000-0002-9816-2520, PhD student, Marmara University, Institute of Educational Sciences, memet_karali@hotmail.com
} 


\section{INTRODUCTION}

The societies are social structures that have maintained the existence of people throughout history, have common values and distinguish themselves with their unique lifestyle. People as social beings; although they are living beings that have personal differences in the world they are equipped with certain features, they gain their social identity by adopting the unique characteristics of the society. This identity is realized in the process of socialization. This identity is realized in the process of socialization (Çoştu, 2009). The societies use many different ways in the process of transferring their individual characteristics. An important part of this culture transfer which has been going on for centuries has been falling into the field of education. The societies that emerged as a result of the necessity of people living together have important responsibilities for educational activities in order to transfer their cultural properties, values and beliefs to younger generations from the past. According to Gökçe (2014), education is a process that prepares individuals for social life. Individuals socialize through education and understand the cultural elements of society. Ertürk (1997) defines education as a desired change in the behavior of individuals through their own lives. According to Şişman (2007), the visible changes in the behavior of the individual as a result of the education process should be permanent as a result of the individuals' own lives. Durmuşoğlu, Yanık and Akkoyunlu (2009) define education as a process in which cultural transmission is carried out in line with the needs of the society in which individuals live.

Social studies education, as well as being the main actor in today's changing societies, is seen as an important way to create a learning society by supporting people in solving their daily problems (Etsuko, 2009). All events leading the social life can be covered by social studies. A historical phenomenon, a geographical event, a legal concept and our rights and responsibilities as citizens are examples.

Transfer to individuals in the scope of social studies of values that existed from the past and helping to keep the society together reveal the importance of social information. Deveci (2010) stated that social information plays a socially important role and revealed the importance of social information by establishing a direct relationship between the future state of social information and the future of our world. Öztürk (2006) points out the social information as the course where the values that bring society together in the common denominator are conveyed in educational institutions. According to Kabapinar (2007); social sciences is a simplified version of social sciences for students and social studies course is the course where students are informed about social sciences. Barth and Demirtaş (1997) describe social knowledge as a lesson plan in which individuals gain the skills they will use throughout their lives. The social studies course aims to enable individuals to be in harmony in the society they live in and to gain social personality to be good citizens (Aykaç, 2007).

Aslan (1992) describes as personality that the person's thoughts, their perception of the world, their adaptation to the environment and their reactions to the events that take 
place around him, it refers to a sub-dimension of personality as self. Bacanll (2005) defines the concept of self as the way people perceive themselves. According to Özyürek (2005), it is a situation that occurs during the interaction of the individuals with the close environment and as a result of their environmental relations. When the studies about the self are examined, it is seen that the first studies were made by James, Cooley and Mead (Soğukpınar, 2014). "The Theory of Possible Self", which suggests that self is a multidimensional concept, was first put forward by Markus and Nurius (1986) in the field of personality psychology. According to Markus and Nurius (1986, p. 955), the possible selves are ideal selves who would be happy to be individuals. There are three different types of self in the possible selves. The expected selves are the self they think of the activities that individuals can do with a realistic approach. The expected self-ego includes the self of success, the creative self, the rich self, and the weak self, the loved or admired self. The feared self is the type of self that they fear to be in their later life and they want to prevent it. Possible selves represent ideas of what individuals might be, what they want to achieve, and what they are afraid of, and thus provide a conceptual link between cognition and motivation. From the individual's own potentials, the area that provides us with an idea of the future, the realistic thoughts and the future life of fear is the area of possible selves. From the individual's own potentials, the area that provides us with an idea of the future, the realistic thoughts and the future life of fear is the area of possible selves. Possible selves are the cognitive components of individuals' hopes, goals and fears (Markus, \& Nurius, 1986, p. 955). The possible theory of selftheory is important to reveal the differences between the present and future selves in the development of teacher identity and to create ideas for the current teacher identity. As a theory, probable ego have a theoretical framework for inferring teachers by examining their teachers' identities in the process of stepping out from being a student and being a teacher to the last stage of teacher education. According to Hamman \& Wood-War (2007), the prospective teachers will have possible self and will be able to develop their self-development by adopting many different teachers from positive and negative aspects. The answer to the question of the teacher candidates who are in the last year of education faculties and who are preparing for teaching and what kind of teacher they want to become when they start the profession is very important in the development of their professional identity. The possible theory of self-concept helps us to reveal the self-directedness of the prospective teachers who will begin their professions or the teachers of the early years of their professions (Markus and Nurius, 1986, p. 954). Taking into account the importance of teachers' professional identities in enhancing the quality and quality of education, it will help us to have an idea about the self (expected, expected and feared) of the possible self-theory that the prospective teachers will have in their professional years.

\section{Aim and Questions of Research}

This research was prepared to investigate the relationship between pre-service teacher identity levels and possible self-level of pre-service social studies teacher candidates. The basic problem statement of this study; In What is the relationship between pre- 
service teacher identity levels of social studies teacher candidates and their possible self?" creates the question.

\section{METHOD}

\section{Research Design}

This study, which was conducted in order to reveal the relationship between pre-service teacher identity levels and possible self-level of social studies teacher candidates is a descriptive study in relational screening model. The purpose of screening research is to make a photograph by taking a picture of the current situation related to the research subject. The screening models to be used in the research are divided into two as case study models and general screening models. In the general survey models, two or more variables are examined in order to determine the relationships between them are the model relational screening model (Büyüköztürk, Kılıç Çakmak, Akgün, Karadeniz, \& Demirel, 2016).

\section{Participants}

Participants of the study; is comprised of 290 students studying 3rd and 4th grade in Social Studies Teaching Department of Uşak, Muğla Sitkı Koçman, Afyon Kocatepe and Aksaray Universities. Table 1 shows the information of the participants.

Table 1.

Distribution of Data by Demographic Characteristics of Participants

\begin{tabular}{llll}
\hline Variables & Groups & $\mathrm{N}$ & $\%$ \\
\hline \multirow{3}{*}{ Gender } & Female & 158 & 54,5 \\
& Male & 132 & 45,5 \\
& Total & 290 & 100 \\
\hline \multirow{3}{*}{ Age } & $17-20$ & 23 & 7,9 \\
& $21-23$ & 228 & 78,6 \\
& 24 and Over & 39 & 13,4 \\
& Total & 290 & 100 \\
\hline \multirow{3}{*}{ University } & Muğla Sitkı Koçman University & 65 & 22,4 \\
& Uşak University & 92 & 31,7 \\
& Afyon Kocatepe University & 59 & 20,3 \\
& Aksaray University & 47 & 25,5 \\
& Total & 290 & 100 \\
\hline \multirow{2}{*}{ Class Level } & 3. Level & 169 & 58,3 \\
& 4. Level & 121 & 41,7 \\
& Total & 290 & 100 \\
\hline
\end{tabular}




\section{Data Collection Instrument}

In order to reach the aim stated in the research benefited from demographic form developed by the researcher, teachers Candidates Possible Self-Estimation Scale adapted to Turkish by Dalioğlu and Adıgüzel (2015) developed by Hamman et al. (2013), the PreService Teacher Identity adapted to Turkish by Arpacı and Bardakçı (2015) developed by Freasen and Besley (2013).

The Pre-Service Teacher Identity Scale consists of 17 items in 5-point Likert-type. The internal consistency (cronbach's Alpha) coefficient of the Pre-Professional Teacher ID scale was 0.87 during the adaptation to Turkish language. The scale consists of three sub-dimensions: confidence in being a teacher, self-categorizing as a teacher and participation as a teacher. Possible selves and feared possible selves The Scale of Possible Selves Teacher Candidates consists of the form of two separate six-Type Likert type scales. Both scales are evaluated separately and the two scales have subdimensions. There are sub-dimensions of teaching, inadequate classroom management, and irrelevant teacher, which are not on the scale of possible teacher identities. The internal consistency (Cronbach's Alpha) coefficient of the data obtained from the prospective teacher self scale was calculated as 0.93 . The internal consistency (Cronbach's Alpha) coefficient of the data obtained from the prospective teacher fearful self scale was calculated as 0.92 .

\section{Data Analysis}

After the data collection tools to be used in the research were applied to the participants, all the data were checked by the researcher. The controlled data was transferred to the computer for analysis purposes. Statistical analysis of data transferred to computer environment was performed. In this study, "Is there a relationship between preprofessional teacher identity levels and possible self-efficacy of social studies teacher candidates?" the relationship between pre-professional teacher identity levels and possible self levels of teacher candidates for the problem was questioned. The data obtained from the study were analyzed using "Pearson Product Moment Correlation Analysis"

In this research, the positive relationship between the two variables is the correlation coefficient, is excellent in the direction of 1.00, -1.00 reveals that there is an excellent relationship if it is to be in the negative direction. In the interpretation of the correlation coefficient, the following values are taken into account;

*High and positive in the range of 0.70-1.00

*Moderate and positive direction in the range of 0.70-0.30

*There is a low and positive relationship between 0.30-0.00 (Büyüköztürk, 2017).

\section{FINDINGS}

In this part of the research, the findings obtained within the framework of the basic problem of the research are given. 
Table 2.

The relationship between pre-service social studies teachers' identities and their possible self

\begin{tabular}{|c|c|c|c|c|}
\hline & & $\begin{array}{l}\text { Pre-Professional } \\
\text { Teacher Identity }\end{array}$ & $\begin{array}{l}\text { Expected } \\
\text { Possible Self }\end{array}$ & $\begin{array}{l}\text { Feared } \\
\text { Possible } \\
\text { Self }\end{array}$ \\
\hline \multirow{3}{*}{$\begin{array}{l}\text { Pre-Professional } \\
\text { Teacher Identity }\end{array}$} & Pearson R & 1 & ,500* &,$- 368 *$ \\
\hline & $\mathrm{P}$ & & ,000 & ,000 \\
\hline & $\mathrm{N}$ & 290 & 290 & 290 \\
\hline \multirow{3}{*}{$\begin{array}{l}\text { Trust About Being A } \\
\text { Teacher }\end{array}$} & Pearson R & ,901* & ,393* &,$- 323^{*}$ \\
\hline & $\mathrm{P}$ & ,000 &, 000 & ,000 \\
\hline & $\mathrm{N}$ & 290 & 290 & 290 \\
\hline \multirow{3}{*}{$\begin{array}{l}\text { Categorizing Yourself } \\
\text { As A Teacher }\end{array}$} & Pearson R & ,876* & ,485* &,$- 375^{*}$ \\
\hline & $\mathrm{P}$ & ,000 &, 000 & ,000 \\
\hline & $\mathrm{N}$ & 290 & 290 & 290 \\
\hline \multirow{3}{*}{$\begin{array}{l}\text { Participation As } \\
\text { Teacher }\end{array}$} & Pearson R & ,926* & ,479* &,$- 309 *$ \\
\hline & $\mathrm{P}$ & 000 &, 000 & ,000 \\
\hline & $\mathrm{N}$ & 290 & 290 & 290 \\
\hline \multirow{3}{*}{$\begin{array}{l}\text { The Scale Of Possible } \\
\text { Selves Expected Of } \\
\text { Teacher Candidates }\end{array}$} & Pearson R & ,500* & 1 &,$- 275^{*}$ \\
\hline & $\mathrm{P}$ & ,000 & & ,000 \\
\hline & $\mathrm{N}$ & 290 & 290 & 290 \\
\hline \multirow{3}{*}{ Professionalism } & Pearson R & ,498* & ,949* &,$- 280^{*}$ \\
\hline & $\mathrm{P}$ & ,000 & ,000 & ,000 \\
\hline & $\mathrm{N}$ & 290 & 290 & 290 \\
\hline \multirow{3}{*}{ Learning To Teach } & Pearson R & $445^{*}$ & ,941* & $-240^{*}$ \\
\hline & $\mathrm{P}$ & ,000 & ,000 & ,000 \\
\hline & $\mathrm{N}$ & 290 & 290 & 290 \\
\hline \multirow{3}{*}{$\begin{array}{l}\text { The Scale Feared } \\
\text { Possible Selves Of } \\
\text { Teacher Candidates }\end{array}$} & Pearson R &,$- 368^{*}$ &,$- 275^{*}$ & 1 \\
\hline & $\mathrm{P}$ & 000 & ,000 & \\
\hline & $\mathrm{N}$ & 290 & 290 & 290 \\
\hline \multirow{3}{*}{ Non-Creative Teaching } & Pearson R &,$- 343^{*}$ &,$- 321^{*}$ & ,920* \\
\hline & $\mathrm{P}$ & ,000 & ,000 & ,000 \\
\hline & $\mathrm{N}$ & 290 & 290 & 290 \\
\hline
\end{tabular}




\begin{tabular}{lllll}
\hline Insufficient Classroom & Pearson R &,$- 277^{*}$ &,$- 113^{*}$ &, $816^{*}$ \\
Management & $\mathrm{P}$ &, 000 &, 000 &, 000 \\
& $\mathrm{~N}$ & 290 & 290 & 290 \\
\hline Being An Irrelevant & Pearson R &,$- 365^{*}$ &,$- 305^{*}$ &, $941^{*}$ \\
Teacher & $\mathrm{P}$ &, 000 &, 000 &, 000 \\
& $\mathrm{~N}$ & 290 & 290 & 290 \\
\hline
\end{tabular}

When Table 2 is examined, it is found that there is a moderate, linear and positive relationship between pre-service teacher identity levels of pre-service teachers and possible self-expected levels of social studies teacher candidates [Pearson $R=0,500$; $p$ $=0,000<0,001]$. From this point on, it is observed that prospective social studies teacher candidates ' level of self is increasing as the level of pre-professional teacher identification increases and prospective teachers ' levels of self are decreasing as teacher identity levels of pre-professional teachers are reduced.

Social studies teacher candidates were found to have a middle level, linear and negative relationship between pre-professional teacher identity levels and possible self-fear levels [Pearson $R=-0,368 ; p=0,000<0,001$ ]. From this point, it is observed that social studies teacher candidates have decreased the level of self perceived as being feared as the level of pre-professional teacher identification increases and that social studies teacher candidates have increased the level of self-perceived fear as their preprofessional teacher identity levels decrease.

Looking at the sub-dimensions of pre-vocational teacher identity levels, it was found that there was a moderate, linear and positive relationship between the sub-dimension of trust the expected levels of self of being a teacher [Pearson $R=0,393 ; p=0,000<$ $0,001]$. Hence, as social studies teacher candidates' level of confidence in being a teacher increases, the expected levels of self-esteem are increasing and as the level of confidence in being a teacher decreases, the expected levels of self are decreasing. The relationship between the sub-dimension of confidence in being a teacher of pre-vocational teacher identity and the level of self-confidence that is feared was determined in the middle level, linear and negative way [Pearson $\mathrm{R}=-0,323 ; \mathrm{p}=0,000<0,001]$. Hence, as the level of confidence of teacher candidates about becoming a teacher increases, the potential self-feared levels decrease and as the level of confidence in being a teacher decreases, the level of possible self-fear increases.

It was moderately, linearly and positively found that relationship between selfcategorization sub-dimension as a teacher of pre-service teacher identity levels and their expected levels of self [Pearson $R=0,485 ; p=0,000<0,001$ ]. Thus, as the selfcategorization levels of social studies teacher candidates increase, the expected levels of self-esteem are increasing and the lower the level of self-categorization as a teacher, the lower the expected levels of self-esteem. It was found that there was a moderate, linear and negative relationship between feared possible self levels and self-categorization 
sub-dimension as teacher of pre-occupation teacher identity levels [Pearson $R=-0,375$; $\mathrm{p}=0,000<0,001]$. Thus, as the self-categorization levels as teacher of social studies teacher candidates increase, the potential self-feared levels decrease and as the levels of self-categorization as teachers decrease, the level of self-confidence that is feared increases.

It was found that there was a medium, linear and positive relationship between subdimension participation as teacher of pre-service teacher identity levels and the expected levels of self-esteem [Pearson $\mathrm{R}=0,479 ; \mathrm{p}=0,000<0,001]$. Thus, as the level of participation of teacher candidates in social studies teacher's increases, the expected levels of self-esteem are increasing and as the levels of participation as teachers decrease, the expected levels of self-esteem are decreases. It was found that there was a moderate, linear and negative relationship between sub-dimension of participation as teachers. Pre-occupational teacher identity levels and feared possible levels of self [Pearson $\mathrm{R}=-0,309 ; \mathrm{p}=0,000<0,001]$. Thus, as the level of participation of teacher candidates in social studies teachers increased feared possible levels of self decreased and as the levels of participation as teachers decrease, the level of self-confidence that is feared increases.

It was found that there is a low, linear and negative relationship between the feared possible levels of self and the possible self-esteem levels of social studies teacher candidates [Pearson $\mathrm{R}=-0,275 ; \mathrm{p}=0,000<0,001$ ]. Thus, it is observed that as expected levels of self-esteem of social studies teacher candidates increased, feared possible selflevel decreased and as expected levels of self-esteem decreased, feared possible selflevel increased.

When we look at the sub-dimensions of the expected self-esteem levels of social studies prospective teachers by taking into consideration Table 2, it was found that there was a moderate, positive and positive relationship between the sub-dimension of professionalism and pre-service teacher identity levels Pearson $R=0,498 ; p=0,000<$ 0,001]. From this point on, as the level of professionalism of social studies teacher candidates increases, the level of pre-professional teacher identity increases, and the level of professionalism decreases, the level of pre-professional teacher identity decreases. It was found that there was a low, linear and negative relationship between the level of professionalism sub-dimensions of the expected ego levels of social studies teacher candidates and the possible levels of self-fear that were feared [Pearson $\mathrm{R}=-$ $0,280 ; p=0,000<0,001]$. Thus, as the level of professionalism of pre-service teachers increases, the level of possible self-fear decreases and as the level of professionalism decreases, the potential levels of self-fear are increased.

Considering the sub-dimensions of the expected levels of the possible self-esteem of social studies prospective teachers by taking into consideration Table 2, it was found that there was a medium, linear and positive relationship between the sub-dimension of teaching and sub-teacher learning levels [Pearson $\mathrm{R}=0,445 ; \mathrm{p}=0,000<0,001]$. Thus, as the level of learning pre-service teachers' levels of teaching increase, the pre-service 
teacher identity levels increase and the levels of pre-service teacher identity decreases as the levels of learning to teach decrease. It was found that there was a low level, linear and negative correlation between the sub-dimension of learning to teach the expected levels of the possible self-esteem social studies prospective teachers and the possible levels of self-esteem that were feared [Pearson $R=-0,240 ; p=0,000<0,001$ ]. Thus, as the level of learning to teach social studies teachers' increases, as the learning levels of teaching decrease, the levels of possible self-fear that is feared increases.

Considering the sub-dimensions of possible levels of self-fear of social studies teacher candidates ' taking into consideration Table 2, it was found that there was a moderate, linear and negative relationship between pre-service teacher identification levels and non-creative teaching sub-dimension [Pearson $\mathrm{R}=-0,343 ; \mathrm{p}=0,000<0,001$ ]. Thus, as non-creative teaching levels of social studies teacher candidates increase, pre-service teacher identity levels decrease and as non-creative teaching levels decrease, preservice teacher identity levels increase. It was found that there was a moderate, linear and negative relationship between the non-creative teaching sub-dimension of the feared possible self-level of the social studies teacher candidates and the possible selfexpected levels [Pearson $\mathrm{R}=-0,321 ; \mathrm{p}=0,000<0,001$ ]. Thus, as the levels of non-creative teaching of social studies teachers increase, the possible self-expected levels are decreasing and as the levels of non-creative education decrease, the possible levels of self expected increase.

Considering the sub-dimensions of possible feared self-esteem levels of social studies pre-service teachers by taking into account Table 2, it was found that there was a low, linear and negative relationship between insufficient class management sub-dimension and pre-service teacher identification levels [Pearson $\mathrm{R}=-0,277 ; \mathrm{p}=0,000<0,001]$. Hence, as level of inadequate classroom management of social studies teacher candidates' increases, pre-service teacher identity levels decrease and as the level of inadequate classroom management decreases. Pre-service teacher identification levels increase. It was found that there was a low, linear and negative relationship between the inadequate class management sub-dimension of the feared possible self-level of social studies teacher candidates and the possible self-esteem levels expected [Pearson $R=-0,113$; $\mathrm{p}=0,000<0,001]$. Thus, as the level of inadequate classroom management of social studies teacher candidates increases, the expected levels of self are decreasing and as the level of inadequate classroom management decreases. The expected levels of selfesteem increase.

Considering the sub-dimensions of possible feared self-esteem levels of social studies teachers' candidates by taking into consideration Table 2, it was found that there was a moderate, linear and negative relationship between pre-service teacher identification levels with the sub-dimension of being an indifferent teacher [Pearson $R=-0,365$; $p=0,000<0,001]$. Therefore, as their level of being indifferent teachers of social studies teacher candidates increase, pre-service teacher identity levels decrease and as the levels of being indifferent teachers decrease, pre-service teacher identity levels are increasing. Looking at the sub-dimensions of possible feared self-esteem levels of social 
studies teacher candidates, it was found that there was a moderate, linear and negative relationship between the sub-dimensions of irrelevant teacher and the expected levels of self-esteem [Pearson $\mathrm{R}=-0,305 ; \mathrm{p}=0,000<0,001]$. Thus, as the level of being an indifferent teacher of social studies teacher candidates increases, the expected levels of self-esteem are decreasing and as the level of being an indifferent teacher increases, as the levels of being indifferent teachers decrease, the expected levels of self-esteem are increasing.

\section{RESULTS, DISCUSSIONS AND SUGGESTIONS}

This research is to show that there is a moderate positive relationship between preservice teacher identity levels and possible levels of self of social studies teacher candidates.

In his study, it has been observed that it has reached the conclusion that it is associated with positive and meaningful levels of expected possible self-identities with the identity of a pre-professional teacher desire to achieve professional goals of teacher candidates ' in studying titled "Teacher Candidates' Desire To Achieve Professional Goals And Their Beliefs About Their Accessibility: The Role Of Teacher Identity And Possible Self" in his study and teachers candidates in the department elementary mathematics, pre-school, special education and Turkish teacher education teacher candidates in previous studies in the field Çetin (2017). This result coincides with the results of our study. As a result of weak association in their desire to achieve professional goals of teacher candidates the feared possible selves obtained in the same study, this study is parallel to the other findings of the study.

In their study with Tavşanlı and Saraç (2016) class teachers with in their study titled "Examination Using a Scale of Possible Selves the Teacher Candidates of Occurring Possible Teacher Identities of the Primary School Teacher Candidates", they concluded that the demographic characteristics of the participants were effective in their possible self and teacher identities. This result is important in terms of basing the findings we have reached in the study. When talking about possible self-identities, a concept of one's future self, James (1950, p. 193, as cited in Yllmaz, 2016) stated that the person would avoid failure in the event of realization of these possible identities. This statement supports the conclusion that there is a negative relationship between the feared possible self and the pre-professional teacher identity.

In this study show that the of social studies teacher candidates are contradict with the results of moderate relationship and in the positive direction between the expected selfesteem levels of the teacher and the positive self-confidence levels of the teacher that the results of the study of Özabaci and Acat (2005) found that the teacher candidates they reached had perceptions that the characteristics that they considered necessary to be in the ideal teacher were not sufficient in themselves.

In this study, a total of 290 social studies teacher candidates were investigated in the relationship between pre-professional teacher identity levels and possible levels of self. 
The results of the study revealed that had a positive and moderate relationship between pre-professional teacher identity levels and expected levels of self. In the study shows that there is a negative-sided middle-level relationship between pre-professional teacher identity levels and possible self-fear levels of social studies teacher candidates. In the study was found to be a negative-oriented, low-level relationship among expected self-identities and feared self-identities.

The existence and level of the relationship between the sub-dimensions of two different scales used within the scope of the research were studied. It was observed that there was a positive relationship between the level of confidence of teacher candidates in social studies and their expected self. It has been observed that there is a negative and medium level relationship between social studies teacher candidates' confidence levels about being a teacher and their possible self-fear. It has been determined that there is a positive relationship between social studies teacher candidates' self-categorization levels and their expected self as teachers. It was found that there was a negative and moderate relationship between social studies teacher candidates' self-categorization levels as teachers and their possible self-fear. It has been determined that there is a positive relationship between social studies teacher candidates' level of participation as teachers and their expected possible selves. It was found that there was a negative and medium level relationship between social studies teacher candidates' level of participation as teachers and their possible self-fear.

It was found that there was a positive and medium level relationship between the levels of professionalism of the possible self-esteem scale and pre-service teacher identity. It was found that there was a negative and low-level relationship between the levels of professionalism of social studies teacher candidates and the possible levels of self-fear feared. It was found that there was positive and moderate level relationship between the learning to teach social studies teacher candidates and the level of pre-service teacher identification. It was found that there was negatively low level of relationship between the learning to teach social studies teacher candidates and the possible self being feared.

It has been found that there is a negative relationship between levels of non-creative teaching the possible self-scale of social studies teacher candidates and and pre-service teacher identification levels. It has been found that there is a negative relationship between between the non-creative teaching levels of possible self-esteem scale of social studies teacher candidates and the expected levels of self-esteem. It was observed that there was a negative low relationship between pre-service teacher identity levels and inadequate classroom management levels of social studies teachers' candidates. It has been observed that there is a negatively low relationship between social studies teacher candidates' inadequate class management levels and the expected levels of self-esteem. It was found to be moderate in the negative direction between levels of being an indifferent teacher studies teacher candidates and pre-service teacher identification levels. It has been found that there is a negative correlation between social studies teacher candidates' level of being indifferent teachers and their expected levels of self. 


\section{References}

Aslan Yılmaz, H. (2016). A Review: Some approaches and definitions related to the concept of self. Journal of Social Sciences, 48, 79-89.

Aslan, E. (1992). The concept of self and the effects of the individual's life. Marmara University Atatürk Faculty of Education Journal of Educational Sciences, 4, 7-14

Aykaç, N. (2007). Teachers' views on primary education social studies curriculum. Journal of Electronic Social Sciences, 6(22), 46-73.

Bacanlı, F. (2005). Examining the compatibility between the self-concept and professional self-concept of psychological counselor candidates: a longitudinal study. Educational Sciences in Theory and Practice, 5(2), 586-616.

Barth, J., \& Demirtaş, A. (1997). Primary social studies teaching. Ankara: YOK / World Bank Publications.

Büyüköztürk, Ş. (2017). Data analysis manual book (23. Printing). Ankara: Pegem Academy Publications.

Büyüköztürk, Ş., Çakmak, K. E., Akgün, Ö. E., Karadeniz, Ş., \& Demirel, F. (2016). Scientific research methods (21. Edition). Ankara: Pegem Academy Publications.

Çetin, G. (2017). The prospects achievement of professional objectives of teacher candidates' and their beliefs about their accessibility: the role of teacher identity and possible self. Unpublished Master Thesis, Abant Izzet Baysal University, Institute of Educational Sciences, Bolu.

Çoştu, Y. (2009). A sociological evaluation on the concept of socialization. Journal of Dinology Researches, 9(3), 117-140.

Deveci, H. (2010). Social studies education in the history of Turkish education. Turan, R. \& Ulusoy, K. (Ed.). Fundamentals of social studies (pp.20-56). Ankara: Maya Academy.

Durmuşoğlu, M. C., Yanık, C., \& Akkoyunlu, B. (2009). Attitudes of Turkish and Azeri teacher candidates towards the teaching profession. Journal of Hacettepe University Faculty of Education, 36, 76-86.

Ertürk, S. (1997). Curriculum Development in Education. Ankara: Meteksan Publishing.

Etsuko, Y. (2009). New trends in the study of social education. Educational Studies in Japan: International Yearbook, 4, 27-35.

Gökçe, F. (2014). State and education in the process of change (6. Printing). Ankara: Pegem Academy.

Hamman, D., \& Wood-Harp, C. (2007). Possible selves theory and why new teachers leave. International Journal of Arts \& Sciences, 2(1), 1-3.

Kabapınar, Y. (2007). Teaching life and social studies in primary education. Ankara: Pegem Academy Publishing.

Markus, H., \& Nurius, P. (1986). Possible selves. American Psychologist, 41(9), 954-969. 
Özabacl, N., \& Acat. M. B. (2005). Comparison of Teacher Candidates ' Perceptions of Their Own Characteristics and Ideal Teacher Characteristics. Journal of Educational Administration Theory and Practice, 42, 211-236.

Öztürk, C. (2006). Social studies: an interdisciplinary perspective on social life. Constructivist approach to teaching life science and social studies. Ankara: Pegem Academy Publishing.

Özyürek, M. (2005). Approaches to individual differences. Ankara: Root Publishing.

Soğukpınar, E. (2014). Examination of the level of self-esteem and professional self-esteem of guidance teachers in terms of various variables. Unpublished Master's Thesis, Inönü University, Institute of Educational Sciences, Malatya.

Sunal, C. S., \& Haas, M. E. (2005). Social studies for elementary and middle grades a constructivist approach (2th Edition). Pearson Education.

Şişman, M. (2007). Introduction to educational science. Ankara: Pegem Publications 